\section{Semarang State University Undergraduate LAWE SOCIETY REVIEW}

VOLUME 1 ISSUE 2, JULY 2021
ISSN (Print): 2807-8225 ISSN (Online): 2807-8683

History of Article

Submitted: December 2020

Revised: April 2021

Accepted: June 2021

How to cite:

Naefi, M. (2021). Future Challenge of the Freedom of Religion Act: Comparing Indonesia and Malaysia. Semarang State University Undergraduate Law and Society Review, 1(2), 125140. https://doi.org/10.15294/lsr.v1i2.50551

(C) 2021 Authors. This work is licensed under a AttributionNonCommercial-ShareAlike 4.0 International (CC BY-NC-SA 4.0). All writings published in this journal are personal views of the authors and do not represent the views of this journal and the author's affiliated institutions.

\title{
Future Challenge of the Freedom of Religion Act: Comparing Indonesia and Malaysia
}

\author{
Muhammad NAEFI \\ Faculty of Law, Universiti Utara Malaysia \\ Sintok, 06010 Bukit Kayu Hitam, Kedah, MALAYSIA \\ 凶naefi10@gmail.com
}

\begin{abstract}
Indonesia is one of the countries that uphold human rights International one of the examples is the freedom of religion or embrace religion. It is proven by the inclusion of one of the international human rights values into our constitution namely article 28 I paragraph (1) of the 1945 Constitution. As a sovereign country, Indonesia is obliged to protect the right of its citizens to embrace the religion or belief adopted without any compulsion from any party. Every citizen has the freedom to determine his or her faith or belief according to the mind and conscience of each. So Human Rights are rights that protect us to live together in society without any disturbance. The right to freedom of religion becomes
\end{abstract}


important issue. This study aims to analyze and describe the freedom of religious act in Indonesia and Malaysia in the perspective of human rights.

KEYWORDS. Human Rights; Freedom of Religion; Citizens Rights

\section{INTRODUCTION}

Human rights in Indonesia are used for the appellation of human rights, in Dutch itself Human Rights is a translation of "grondrechten". Some people call it the term fundamental rights. Actually, the definition of human rights is the transfer of the French language "droits de l'homme", while the complete series reads Declaration "des droits de l'homme et du Citoyen", which is about the statement of human rights and French citizens who proclaimed their independence in 1789 , as a reflection of the success of the revolution of its citizens which is free from the restrictions of the country's sole ruler at that time (Sodikin, 2013). Freedom of Religion or Belief (FORB) always has more appeal to be discussed in view of religious and social development and politics, always in touch with human rights issues.

The principle of human rights is the inherent right of every human being that must be protected so that human rights are always the core material in the Constitution of the Modern State (Asshiddiqie, 2007), including the material of the 1945 Constitution of the Republic of Indonesia after the amendment. In the context of freedom of religion, the principle of democracy is an ideal political concept because it is built on the consciousness of human beings as freedom of will. Democracy is often interpreted as a freedom to express opinions so that the limitation of religion is considered contrary to the principle of democracy itself. That is why the idea of liberalists requires no restrictions on believing in a particular religious belief including not believing in the existence of God. 
If democracy is defined as a freedom of expression and expression, every citizen should be free to express in accordance with his religious beliefs. However, it cannot be imagined how disruptive a country would be if there were no norms that could be used as a rule to regulate every citizen in expressing religious freedom (Hafsin, 2010).

Every human being has the right to think freely, to hear, to see, to express opinions, to express ideas and to embrace a religion. If religious freedom is guaranteed and protected by law and human rights, the consequence of such freedom of religion is freedom for all religions to be religious, and the impact between each religion there is a difference between one another, particularly those relating to theology and dogmatic, and justification. Bringing and bridging the differences between religions and between religious communities is a difficult and sensitive matter, when no mutual respect, tolerant, and persuasive effort is made (Johanis, 2014). In reality, some modern Muslim countries have not only implemented the modern constitution that provides civil rights guarantees and treats equally citizens before the law, in fact they have ratified the International Covenant on Civil and Political Rights (ICCPR) which states that the citizens' religious rights are given a strong guarantee in them (Sayogie, 2015).

This research is a normative legal research or literature research that relies on some legal materials such as primary materials, secondary materials, and tertiary legal materials, as follows:

1. Primary legal materials, namely legal materials obtained from a number of laws and regulations, such as the 1945 Constitution of the Republic of Indonesia, the Universal Declaration of Human Rights, and Law no. 39 of 1999 on Human Rights.

2. Secondary legal materials, namely legal materials that can support the understanding of primary legal materials, obtained from the relevant literature. 
3. Tertiary legal material, namely legal material that can explain the material of primary law and secondary law material, obtained from the dictionary or encyclopedia.

The data obtained from various legal materials mentioned above then analyzed by comparative approach (comparative approach).

\section{HUMAN RIGHTS IN INDONESIA: A TERMINOLOGY AND APPLICATION DISCOURSE}

Human rights are natural inherent rights to every biological creature as human beings who give moral and legal guarantees to every human being to enjoy freedom from any form of servitude, oppression, plunder, persecution or any other treatment that causes the human being cannot live properly as a human being glorified by God (Wignjosoebroto, 1996).God Almighty gives the right to every human being that must be respected and appreciated by citizen for the sake of protection and human dignity and prestige (Republic of Indonesia, 2000, Law No. 26/2000). Freedom of religion and belief is not only a matter of state or NGO that is engaged in human rights advocacy and religious freedom, but it is the responsibility of all religious people, both internally and externally with other religious adherents. Thus, freedom of religion is the responsibility of all parties (Yusdani, 2011).

Literally what is meant by human rights is fundamental or basic right (Pujiarto, 1993). In this literal sense, human rights are fundamental rights, so its existence is a must, cannot be contested, even must be protected, respected, and retained from all kinds of threats, obstacles, and gangs of other human beings. Wolhoff provides an explanation of human rights, that human beings have natural rights. These rights cannot be abstracted by anybody, nor can they be transferred from other human beings 
(Wolhoff, 1995). Ramadhon Naning, argues that "Human rights are the inherent rights of human dignity attached to them as the creatures of Allah Almighty One. Or fundamental rights that are principally as divine grace. Means Human Rights It is a human right that demands its nature, which cannot be separated from its essence" (Naning, 1983).

Jhon Locke explains that all individuals have an inherent right to life, liberty and ownership which is their own and is not repealed by the state (Smith, 2008). Anwar Sutan Amiruddin said that human rights are rights that are a gift of God Almighty to every human being that cannot be limited by other human beings unless demanded by the public interest. But such restrictions should not be used by the government arbitrarily to achieve its objectives, because if that happens, the government will lose its legitimacy (Nasution, 1995).

\section{THE PROTECTION OF HUMAN RIGHTS IN INDONESIA}

The State of Indonesia is a country that guarantees the right to freedom of religion and worship as stipulated in Article 29 of the 1945 Constitution (Fatmawati, 2011). Oemar Seno Adji argues that one of the characteristics of the Indonesian Legal State is the absence of rigid and absolute separation between religion and state, and the state is in a harmonious relationship (Adji, 1985), while Muhammad Tahir Azhary argues that one characteristic of the State of Indonesian Law is the close relationship between religion and the state based on the Supreme Godhead, and in the Pancasila State Law should not occur separation between religion and either absolutely or not, because it would be contrary to Pancasila and the 1945 Constitution. 
"Indonesia is a State of Law imbued by Pancasila in the administration of national and state life, so although not a religious state is also not a secular state especially atheist state, but is an Indonesian Law Country, where there is a close relationship between the state and religion, religious matters that require state interference, they must be regulated in legislation, and followed up by various government policies"

According to Law No. 39 of 1999 article 22 on Human Rights regulating the right to freedom of religion and worship, namely:

"1. Everyone is free to embrace their respective religions and worship according to their religion and belief. "

"2. The state guarantees the freedom of every individual to embrace his or her religion and to worship according to his religion and belief."

Referring to Article 28 e Paragraph (2) and Article 29 Paragraph (1) and (2) of the 1945 Constitution, the principles of the article have basically provided guarantees in the Constitution concerning the right to freedom of religion in Indonesia. If widely interpreted, all three explain the same thing about religious freedom, namely: the right to believe in a belief, and the right to express thoughts and attitudes according to the conscience.

The need for regulation of religious life not only accommodates certain religious groups, but because it must be regulated for the sake of order in society. Cases that usually occur in relations between citizens related to religious life are proselytism that is done with unethical, religious defamation, and misuse of religion. Unethical proselytism is a compulsion to convert. Proselytism, which is coercion, in addition to being prohibited in certain state constitutions, is also prohibited in the Cairo Declaration on Human Rights in Islam, which states: "It is forbidden to use coercion in any form to man or to exploit his poverty or ignorance to convert his beliefs to a religion or atheism" (Smith, 2008). 
Pancasila as the basic norm of the State of the Republic of Indonesia as stated in the preamble of the 1945 Constitution becomes the basis of the article and the body which is under it concerning the right in freedom of religion. The first principle in Pancasila which has the meaning or concept that every Indonesian citizen must respect religion and beliefs that are embraced freely without any interference from other parties.

This means not only the prohibition of unethical proselytism, but also the prohibition of blasphemy and misuse of religion within the state of Indonesia as it will lead to disintegration and lead to chaos in society. The rules set forth in the First Precept of Pancasila inspire articles in the body, which are further stipulated in various laws, such as Law Number 39 Year 1999 and Act Number 1 Year 1965.

\section{VIOLATION OF FREEDOM OF RELIGION}

In some countries there are often violations of freedom of religion or belief. Indonesia itself is one of the countries that often get attention related to violations in religion and worship. One country that often gets the spotlight associated with violations of freedom of religion or belief is Indonesia. Despite having many regulations on freedom of religion and belief, Indonesia is not yet free from such violations.

Based on an analysis conducted by Imparsial (2006), the state's violation of freedom of religion or belief uses two modes. First mode, the state indirectly violates by way of omission of various cases that occur so as to cause acts of violence committed by the community. In some cases, the attitude of the security apparatus is letting and not doing prevention, prompting a group of people to continue their actions such as closing the place of worship or attacking the beliefs of other groups. As a party with the authority to control security and order in the community, the security 
forces should take action against the perpetrators of such violence. But not infrequently the security forces do the omission as if the act of perpetrators of violence is justified. The act of omission by the security apparatus according to Imparsial cannot be justified because just as the state does not guarantee and protect against freedom of religion or belief. Whereas in the second mode, the state commits a direct violation through the creation and strengthening of policies that restrict and foster religious and credible (Marpaung, Rusdi, \& Sugiarto, 2006).

Freedom of religion or belief is a part of civil and political rights categorized as a negative right different from social, economic, and cultural rights that are categorized as positive rights. Positive rights (social, economic, and cultural) can be fulfilled if the state plays an active role in promoting it. Conversely, negative rights can be realized if the state does not interfere too much with religious affairs in society (Arifin, 2011).

Logically in practice, freedom of religion cannot be done in absolute terms. When it comes to the level of expression, the establishment of associations and institutionalization of religious freedom becomes relative. This relativism is not due to betrayal of the principle of religious freedom but because of the creation of balance and orderly in the harmony of religious life. That is why the international community also recognizes the principle of relativism of religious freedom as set forth in the International Covenant on Civil and Political Rights (ICCPR). Article 18 of the Covenant contains:

"1. Everyone shall have the right to freedom of thought, conscience and religion. This right shall include freedom to have or to adopt a religion or belief of his choice, and freedom, either individually or in community with others and in public or private, to manifest his religion or belief in worship, observance, practice and teaching." 
"2. No one shall be subject to coercion which would impair his freedom to have or to adopt a religion or belief of his choice."

“3. Freedom to manifest one's religion or beliefs may be subject only to such limitations as are prescribed by law and are necessary to protect public safety, order, health, or morals or the fundamental rights and freedoms of others."

"4. The States Parties to the present Covenant undertake to have respect for the liberty of parents and, when applicable, legal guardians to ensure the religious and moral education of their children in conformity with their own convictions."

According to article 18, paragraph 3 above, the freedom to manifest one's religion or belief shall only be limited by law and the restrictions necessary to protect:

(1) public safety,

(2) public order,

(3) public health,

(4) public morals and public morals

(5) the fundamental rights and freedoms of others.

In Indonesia freedom of religion is relativized with Pancasila and the 1945 Constitution. This means that freedom of religion for the nation of Indonesia is limited by Pancasila and the 1945 Constitution. Thus, if it embraces the ideals of religious freedom absolutism, then Pancasila itself is already limiting freedom of religion. As noted above, the principle of religious freedom places personal conviction as the highest and noble value. Therefore, if a person believes that the god does not exist then the state must provide a space for him and those who share his ideology to be godless. At the level of religious conscience no one, including the state, can 
obstruct this freedom of conscience. Therefore, Pancasila only limits religious freedom of expression level. The First Precepts of Pancasila are, of course, the main elements of the First Precepts in Pancasila. The first precept of the deity of YME "is not only the spiritual basis and moral basis of the nation's life, but implicitly also contains the teachings of religious tolerance (Mahendra, 1996).

Furthermore, when a person expresses himself in a state then that person should behave in the presence of the One, because this is what has become the social contract of anyone born in Indonesia. This principle of "Belief in the Almighty" may not be consistent with the principle of religious freedom in its absolute sense, but this is our social contract as a citizen. Anyone who does not agree with this social contract must be ready not to become an Indonesian citizen. In addition, the lawsuit of judicial review is also contradictory to the 1945 Constitution which clearly relativizes the expression of religious freedom. This can be read clearly from Article $28 \mathrm{~J}$ Paragraph 2 of the 1945 Constitution which states:

"In exercising their rights and freedoms, each person shall be subject to the restrictions laid down by law with the sole intent of ensuring the recognition and respect of the rights of liberty of others and to fulfil fair demands in accordance with moral judgment, religious values, security, and public order in a democratic society"

Based on the above explanation, it can be constitutionally justified if the lawsuit of judicial review against Law No. 1/PNPS/1965 on Prevention of Misuse and / or Blasphemy is not granted by the Constitutional Court. At this point, the Court cannot be blamed for violating the principle of religious freedom. Because what the constitutional justice has done is 
simply keeping the mandate that all the rules under it should not conflict with the constitution as a benchmark for every rule.

As a country with multicultural people like Indonesia, wisdom, and wisdom in understanding freedom as one of human rights and religious as sensitive. Thus, it is hoped that the impact of the understanding of freedom in the framework of a peaceful life in a heterogeneous society can be realized (Sartini, 2008).

The Universal Declaration of Human Rights calls the term human rights, always the most basic and important topics to prioritize, so it is often discussed at the national and international levels. Article 18 of the Universal Declaration of Human Rights consists of three parts. First, guarantee the right to freedom of thought, belief, and religion, which is generally described as an international forum. Second Article 18 discusses the changes and the spread of religion, the right to teach and spread one's religion and the right to engage in the activities of spreading religion into controversial issues. Freedom of conversion and propagation of this religion sometimes conflicts with other rights such as privacy, disturbance to the unity of a group's identity as if ethnicity and religion are closely related and even illegal. Such illegal acts could include abuse of the right to change and propagate religion, coercion of captive audiences and improper use of persuasion. Third Section 18 calls for external forums, or in other words, the manifestation of religious freedom (Lerner, 2010).

Paragraph 7 General Comment of the UN Human Rights Committee pursuant to Article 20, it is not justified the implementation of religious teachings or beliefs that create against the religion of others that lead to discrimination. While paragraph 8 of the General Comment of the UN Human Rights Committee against Article 1830 allows restrictions on practicing religious teachings or beliefs only if they are determined to protect public safety, covenants, health or morals, or other fundamental 
rights and freedoms. Verses 9 and 10 The General Comment of the UN Human Rights Committee calls for the recognition of a religion or ideology to be the official religion or ideology of the state because its followers constitute the majority of the population in a country not to cause discrimination against minority followers of a religion or ideology in that country.

The essence of human rights or freedom of religion contained in the various international instruments mentioned above is covered in eight main components as emphasized by Lerner (2010), as follows:

1. Individuals have the right to freedom to think, to argue, and to embrace a religion. These rights are the basic rights and internal parts of each individual that cannot be interfered with by anyone, because it is directly related to each individual human being with his God.

2. Every human being has the right to perform worship according to his or her own religion without any interference from anyone and from any religion. External freedom in religion teaches humans to be more tolerant of others and not to interfere.

3. Freedom in religion is the right of every human being. No one has the right to prevent a person from embracing a religion.

4. The Government does not discriminate the protection and service of the color of the state either from the religious, tribal, racial, or cultural aspects attached to the private citizens.

5. States shall protect and guarantee the freedom of will by the parents in educating and teaching religious ethics to their children according to their beliefs.

6. Religious community as a binder and amplifier in achieving and upholding the right of independence in freedom of religion.

7. Restrictions on freedom of religion are concerned with the exclusion of every citizen from organizing and managing the internal problems of 
human beings (others), thus causing disruption to one party that may cause social problems.

8. States are not allowed to prohibit and limit the rights of their citizens in choosing and embracing a religion under any pretext.

The right to religion is recognized as part of internationally recognized and internationally recognized human rights in the International Covenant on Civil and Political Rights adopted by the United Nations in 1966, then ratified or ratified into Law Number 12 of the Year 2005. In the provision of Article 18 paragraph (1) states that "Everyone has the right to freedom of thought, conscience and religion."

This right includes freedom to embrace or accept a religion or belief in its own choice, and freedom, either individually or collectively with others, and whether in public or private places to practice their religion or belief in worship, obedience, teaching. In the Declaration on the Elimination of All Forms of Intolerance and Discrimination Based on Religion or Belief adopted by the United Nations in 1981, Article 1 also states that: "Everyone is free to choose and embrace religion, and manifest it personally and in groups, in worship, practice, and teaching."

In the Durban Review Conference document of April 2009, paragraph 13 , it was also stated that UN member states reaffirmed their commitment that all revelations of a religious hatred include discrimination that should be prohibited by law (Radjawane, 2014). Indonesia has a good performance in terms of prescriptive acceptance of international human rights norms.

This matter can be seen from the existence of regulations regulating the right of freedom of religion from the highest (constitution) rule until the explanatory rules under it (Muktiono, 2012). In the Elucidation of Law No. 39 of 1999 also affirmed that to implement the obligations set forth in the 1945 Constitution, the People's Consultative Assembly (MPR) with the MPR Decree No. XVII / MPR / 1998 on Human Rights assigns to state high 
institutions and all government apparatus to respect, uphold and disseminate an understanding of human rights to the whole society, as well as ratify the various instances of the United Nations on Human Rights, as long as it does not conflict with Pancasila (Rahmah \& Sudrajat, 2009).

\section{CONCLUSION}

Based on the analysis that the author has done with various theories obtained through literature study and comparative study, it is concluded that Indonesia is a secular state that separates between religion and government, a country that upholds the right of freedom of religion. So the government does not affect the internal decisions to embrace the religion of each citizen. The government only protects the rights of its citizens in the context of religious freedom. Freedom of religion and belief is not only a matter of state or organization that is engaged in human rights and freedom of religion, but it is the responsibility of all religious people, both internally and externally. Thus, religious freedom is the responsibility of all parties.

\section{REFERENCES}

Adji, O. S. (1985). State Free Trial Law. Jakarta: Erland.

Arifin, S. (2011). Islamic Discourse and Human Rights in Indonesia: Perspective on Religious/Religious Freedom. Journal of Islam Discourse and Human Rights in Indonesia, 14(2).

Asshiddiqie, J. (2007). Principles of Indonesian Constitutional Law Post Reformation. Jakarta: PT Buana Ilmu Populer.

Azhary, M. T. (1992). State of Law: A Study of Its Principles Seen from the aspect of Islamic Law, its Implementation, in the Period of Medina and Current State. Jakarta: Bulan Bintang. 
Fatmawati, F. (2011). Protection of the Right to Freedom of Religion and Worship in Indonesian Law State. Journal of the Constitution, 8(4).

General Comment of the UN Human Rights Committee.

Hafsin, A. (2010). The Thought of Democracy in Indonesia between Restrictions and Religious Freedom. Journal of Analysis, 17(1).

Johanis, M. J. (2014). Protection of Religious Freedom in the Exercise of Worship according to the Perspective on Human Rights. Lex et Societas, 2(1).

Lerner, N. (2010). Nature and Minimum Standards Freedom of Religion or Belief, Freedom of Religion and Beliefs How Far? Yogyakarta: Kanisius. Mahendra, Y. I. (1996). Dynamics of State Administrative Law in Indonesia: Actual Compilation of Problems of House of Representatives and Party System. Jakarta: Gema Insani Press.

Marpaung M., Rusdi, R., \& Sugiarto, J. H. (eds) (2006). Selective Democracy against Human Rights Enforcement: Report on Indonesia's Human Rights Condition 2005. Jakarta: Imparsial.

Muktiono, M. (2012). Assessing the Politics of Legal Freedom of Religion and Belief in Indonesia. Jurnal Dinamika Hukum, 12(2).

Naning, R. (1983). Idea and Image of Human Rights in Indonesia. Jakarta: LKUI.

Nasution, A. B. (1995). Aspirations of Constitutional Governance in Indonesia. Jakarta: Pustaka Utama Grafiti.

Pujiarto, H. (1993). Human Rights in Indonesia a Philosophical Review Based on Pancasila and its Problems in Criminal Law. Yogyakarta: Atmajaya University.

Radjawane, P. (2014). Religious Freedom as a Constitutional Right in Indonesia. Journal Sasi, 20(1).

Rahmah, A. M., \& Sudrajat, T. (2009). Discovery of Law in Concreto in Freedom of Religion and Belief. Jurnal Dinamika Hukum, 9(2).

Republic of Indonesia. (1999). Law on Human Rights, Law No. 30, LN. 165, TLN No. 3886 Year 1999.

Republic of Indonesia. (2000). Law No. 26 of 2000 on Human Rights Courts. 
Sartini, S. (2008). Ethical of Religious Freedom. Journal of Philosophy, 18(3). Sayogie, F. (2013). State Protection of the Right to Freedom of Religion: The Perspective of Islam and Universal Human Rights. Jurnal Hukum PRIORIS, 3(3).

Smith, R. K. M. (2008). Cairo Declaration on Human Rights in Islam. Yogyakarta: PUSHAM UII.

Smith, R. K. M. et., al. (2008). Human Rights Law. Yogyakarta: PUSHAM UII.

Sodikin, S. (2013). Law and Religious Freedom.Journal of Law, 1(1).

Wignjosoebroto, S. (1996). Right to Self-Determination and Human Rights, Panel Discussion Paper, PSPMAA \& NNB UNPAD \& Balitbang DEPLU RI, August 10, 1996.

Wolhoff, W. (1995). Introduction to the Republic of Indonesia Constitutional Law. Jakarta: Timun Mas.

Yusdani, Y. (2011). Freedom of Religion in the Perspective of Human Rights. Journal of Al-Mawarid, 11(2), 268-269.

\section{Conflicting Interest Statement}

All authors declared that there is no potential conflict of interest on publishing this article.

\section{Funding}

None

\section{Publishing Ethical and Originality Statement}

All authors declared that this work is original and has never been published in any form and in any media, nor is it under consideration for publication in any journal, and all sources cited in this work refer to the basic standards of scientific citation. 